\title{
Digital Expression Theory on Everything (DEToE)
}

\author{
Syifaul Fuada \\ Corp Assistant at TE UM \\ Electrical Departement, Faculty of Engineering, \\ State University of Malang (UM), East Java \\ Indonesia
}

\author{
Nur Kamilah \\ Student of Faculty of Letters \\ English Language Teaching, English Departement \\ State University of Malang (UM), East Java \\ Indonesia
}

\begin{abstract}
Communication is a means to send and deliver information and understanding from one to another. Yet, one of the purposes of communication is to deliver a message of feeling and the material usually used in communication is either question or assertion. Besides, images or pictures are a kind of non verbal communication that could represent thousands of words; therefore, pictures, or in this case is best said to be drawing, could cover better messages than words. Further, drawing are expressions that deliver the message of feeling from one to another. Still, it is inevitable that to draw is not easy for some people, but nothing to worry about right now that as the era advancing, computer has come up to be the solution to draw easier. Hence, for drawing, many kinds of industrial standardized software for design are improved, and in fact, they are friendly used. In addition, to result the best drawing so that they could almost resemble the original image, computer technology with high resolution has been upgraded. As the result of the upgraded technology, many of the use of drawing to deliver message in our life, like posters put along the street even in our own bedroom. However, the discussion toward Digital Message in this particular paper is not about posters, but the messages delivered in the form of self-image made by designers in their drawing. Furthermore, the making of the drawing is using techniques of vector, filter, digital sketch, import, and other drawing digital techniques. This paper, in fact, is trying to describe about some theories and implementation of digital expression within pictures in some forms, such as 1) In the Front Cover of Book, 2) In 'Drawing Our People in Our Lives', 3) In 'Say ! Happy Bhirthday', 4) In submitting pictures for a design contest.. Not to mention, acknowledgement towards everyone who has contributed in the designing idea and opinion is included in this paper.
\end{abstract}

\section{General Terms}

Pictorial Message, Graphic Design, Communication, Technology, Computer Technology, Graphic Art

\section{Keywords}

Pictorial Message, Design Software, Digital Expression

\section{INTRODUCTION}

Drawing is one of the products of graphic design in visual form which is the purpose is to deliver information and messages effectively. This visual message is, in fact, easily and quickly accepted by people, as well as the pictorial message.

Nowadays, technology has offered itself to help ease people in doing their activity, not to mention visual designers. If we refer back to the past, drawing was that an activity to draw manually either in the sketching or coloring, but the present time offers easier technique to do those things through computer. Yet, as computer resolution has been improved, the visualization in drawing seems to be 'more real'.

Along with the improvement the computer resolution, types of graphic design software are also improved significantly so that the designers get easier to operate so that they could freely develop their imagination, innovation, and creation towards one object [1]. A designer is supposed to deliver information through drawing, like giving advices [2], suggestive power or opinion [3][5], criticism [4] [21], motivation and so on. Yet, he or she is supposed to freely express his or her ideas and feeling, either the sad, happy, proud, disappointed, or even to express hate or love.

This study is therefore a descriptive study, in which the aim is to describe the expression in digital form or made into digital technique. Instead of dealing with posters, the digital message in this paper is about the description of self-image made or the faces made by designers in order to deliver the message to any particular person or people, in which the process would work with technique of vector, filter, digital sketch, import to, and other drawing digital technique.

\section{HOW DOES EXPRESSION WORK?}

The question above is the basic question about how we could express things in the form of posters or drawings. To refer to the paper by Satish Gajawada (2012) entitled 'Smile Theory of Everything' [6] [7] [8] [9] [16], that smile is the product of our attitude and feeling. Thus, expression, which is related to smile, in drawing or any designed pictures is actually originated from idea and concept from someone's feeling and completed by the characterization, faces, hobbies, activities, and the occupation. Simply in drawing, the ability or skill to make use of design software is not necessary, because just our squiggles on a piece of paper and then scanned to make it a digital file form could help a lot. Finally, that scanned file is what we give to the intended person, so the pictorial message we just made.

\section{THE STATE OF ART}

\section{a. Digital Image File Types}

There are various kinds of picture formats we have and each has its own characteristics, as well as the superiority. Some of extensions commonly used in graphic design world are; 1) Tagged Image File Format (TIFF), 2) Portable Network Graphics (PNG), 3) Joint Photographic Experts Group (JPEG), and 4) Graphics Interchange Format (GIF) [10] [11] [12]. The following paragraphs are the details of extension mentioned above.

TIFF format is good for the need of printing because of the image compression does not too much decrease the quality of the images when saved. It is good for the format is very ideal to use as the standard image file for printing [13]. On the other hand, the weakness of this format is that it is not compatible for web use because the size of the image is too big yet web does not support this TIFF formatting. 
The second one is PNG format. This particular format is the standard format for electronic and internet publishing purpose. Besides, this file format is used as the alternative file format of GIF that can give a transparent background and smooth border [13], and the following paragraph will explain further. However, the weakness of this format is that it is not supported to be opened in internet explorer [10].

Moreover, GIF format, just like the previous formats, has a special quality which is that it is good for the use of animated design for web page and electronic publishing. On the other hand, this format is not suggested for printing and photography purpose for its limited amount of colors that it is only available for 256 colors per image.

Finally, JPEG format file is good for saving image file that would be uploaded to web page, multimedia, or electronic publishing. Due to the superiority of JPEG format, it is the format usually used. Yet, this particular format can save images with RGB, CMYK, and Grayscale type of coloring [11] [12] [13].

\section{b. Paper Size Format}

In drawing, the first thing to consider is that the format set for the paper size. The following is the list of four parts standardized paper size in international world, according to Edsebokks (2004).

1. ISO and JIS Standard Paper Sizes (metric and Japan standards)

2. Metricated Traditional Paper Sizes (used in the UK/EU and Japan)

3. Non metric traditional Paper Sizes Used in North America

4. Commonly Used Paper Sizes Listed by Country

Meanwhile, the most popular paper size used is ISO 216 standard [15]. According to Kuhn (2006), the concept of ISO paper size is;

"In the ISO paper size system, the height-to-width ratio of all pages is the square root of two $(1.4142: 1)$. In other words, the width and the height of a page relate to each other like the side and the diagonal of a square. This aspect ratio is especially convenient for a paper size. If you put two such pages next to each other, or equivalently cut one parallel to its shorter side into two equal pieces, then the resulting page will have again the same width/height ratio" [17]. For better understanding, the following picture could help.

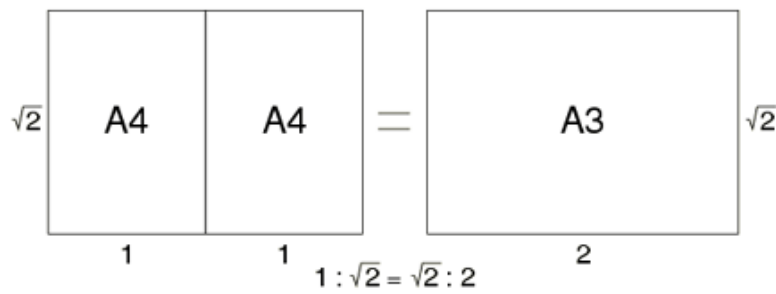

Fig 1: Width and height ratio formula

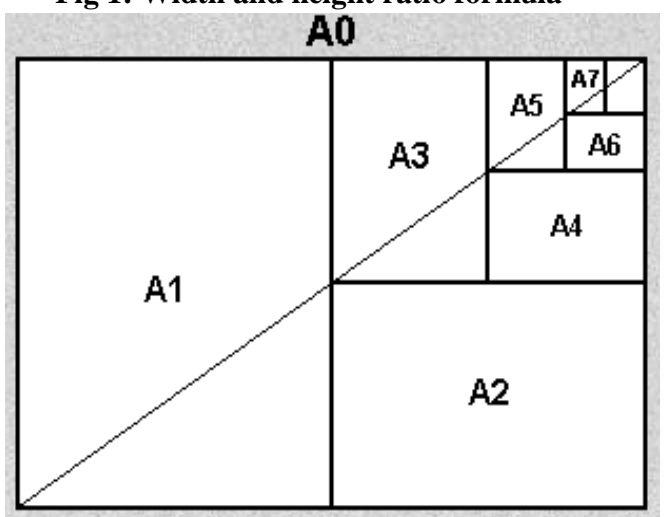

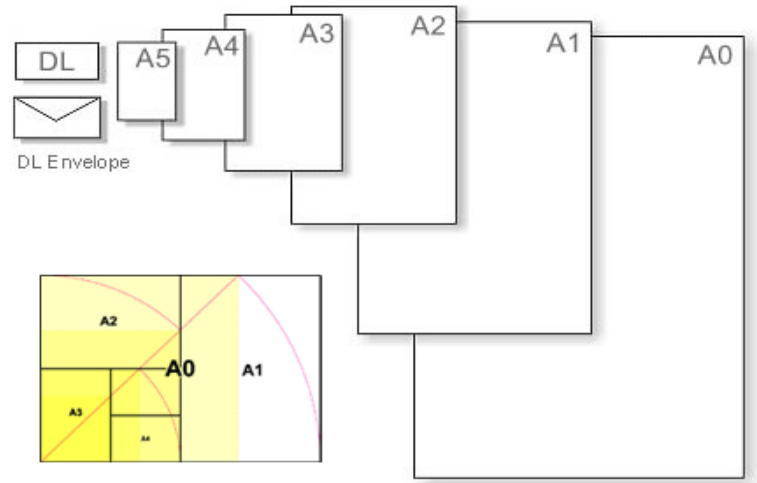

Fig 2: Paper scale on ISO 216 [19] [20]

"The ISO paper size A standard is based on each size being half of the size of the previous one, when folded parallel to the shorter lengths. This system allows for a variety of useful applications, such as the enlarging and reducing of images without any cutoff or margins, or folding to make a booklet of the next size down" [18].

The ISO standard paper size system covers a wide range of formats, but not all of them are widely used in Indonesia. Commonly the size of paper used in Indonesia is A0 - A5. Some main applications of the most popular formats can be summarized as [17]:

Table 1. Applications of the most popular formats

\begin{tabular}{|l|l|}
\hline A0, A1 & technical drawings, scientific posters \\
\hline A1, A2 & flip charts , draw media \\
\hline A2, A3 & drawings, diagrams, large tables, pamflet \\
\hline A4 & $\begin{array}{l}\text { letters, magazines, forms, catalogs, laser printer and } \\
\text { copying machine output }\end{array}$ \\
\hline A5 & note pads, leaflet \\
\hline A6 & Postcards \\
\hline $\begin{array}{l}\text { B5, A5, } \\
\text { B6, A6 }\end{array}$ & books \\
\hline $\begin{array}{l}\text { C4, C5, } \\
\text { C6 }\end{array}$ & $\begin{array}{l}\text { envelopes for A4 letters: unfolded (C4), folded once (C5), } \\
\text { folded twice (C6) }\end{array}$ \\
\hline B4, A3 & $\begin{array}{l}\text { newspapers, supported by most copying machines in } \\
\text { addition to A4 }\end{array}$ \\
\hline B8, A8 & playing cards \\
\hline
\end{tabular}

Table 2. Dimension in milimeters and inches [19] [20]

\begin{tabular}{l|l|l|}
\hline $\begin{array}{l}\text { A series formats } \\
\text { Size }\end{array}$ & inches \\
\hline A0 & $841 \times 1189$ & $33 \times 463 / 4$ \\
\hline A1 & $594 \times 841$ & $233 / 8 \times 33$ \\
\hline A2 & $420 \times 594$ & $161 / 2 \times 233 / 8$ \\
\hline A3 & $297 \times 420$ & $113 / 4 \times 161 / 2$ \\
\hline A4 & $210 \times 297$ & $81 / 4 \times 113 / 4$ \\
\hline A5 & $148 \times 210$ & $57 / 8 \times 81 / 4$ \\
\hline
\end{tabular}




\section{c. Drawing Technique Review}

There are three techniques in designing a pictorial message, which are manual, digital, and combination of both manual and digital. Meanwhile, examples used in this paper are what posters commonly use, for the purpose to make readers easily understand and browse and search others related examples to this descriptive study.

First technique is manual technique, as it names manual, all sketch-making uses the designers own hands. To design manually, the designers therefore need some coloring stuff, such as crayons, felt-tip markers, watercolor, and so on. The following figures are examples of pictorial message designed using manual technique.
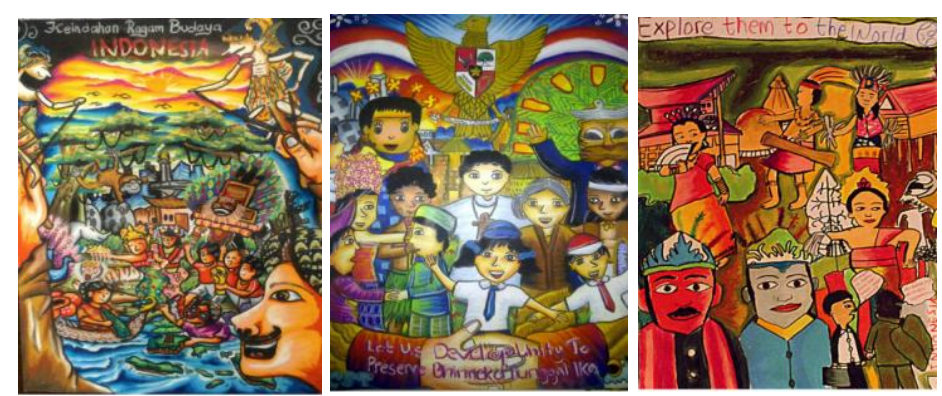

Fig 3: Pictorial Message designed using manual technique downloaded from [29]

Second, designing a pictorial message using digital technique which needs some design software, like Adobe products, Corel Draw, 3Ds, CAD, etc. The making of the sketch in this technique is done directly using the software with vector method. Three of which are using tracking, filter, and export to. Some examples are provided below to help understand deeper.
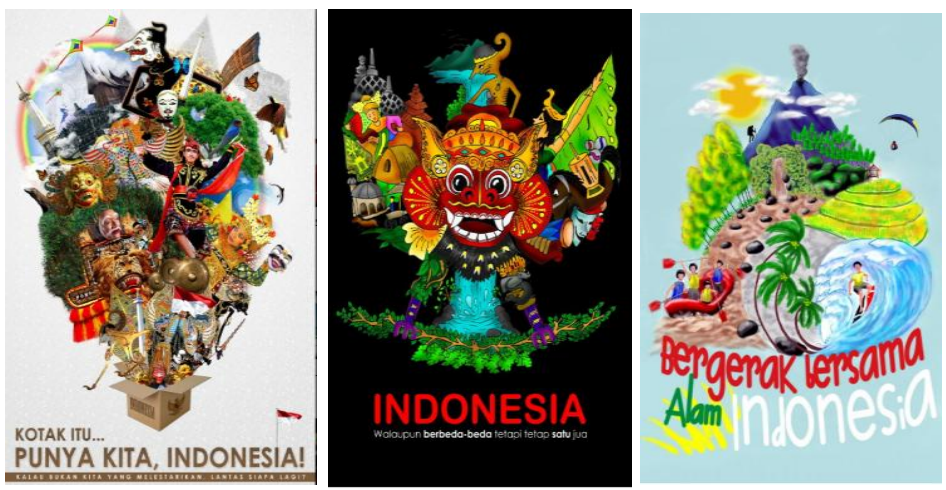

Fig 4: Digital Technique

The last technique is combination technique (manual and digital). Using this technique, designers combine the sketch making manually and digitally as well. The procedure goes this way: the sketch is made using manual technique, and then saved in the form of digital picture file (jpeg, tiff, png, gif), finally, the coloring step is done using design software. The following are examples of pictorial messages using combination technique.
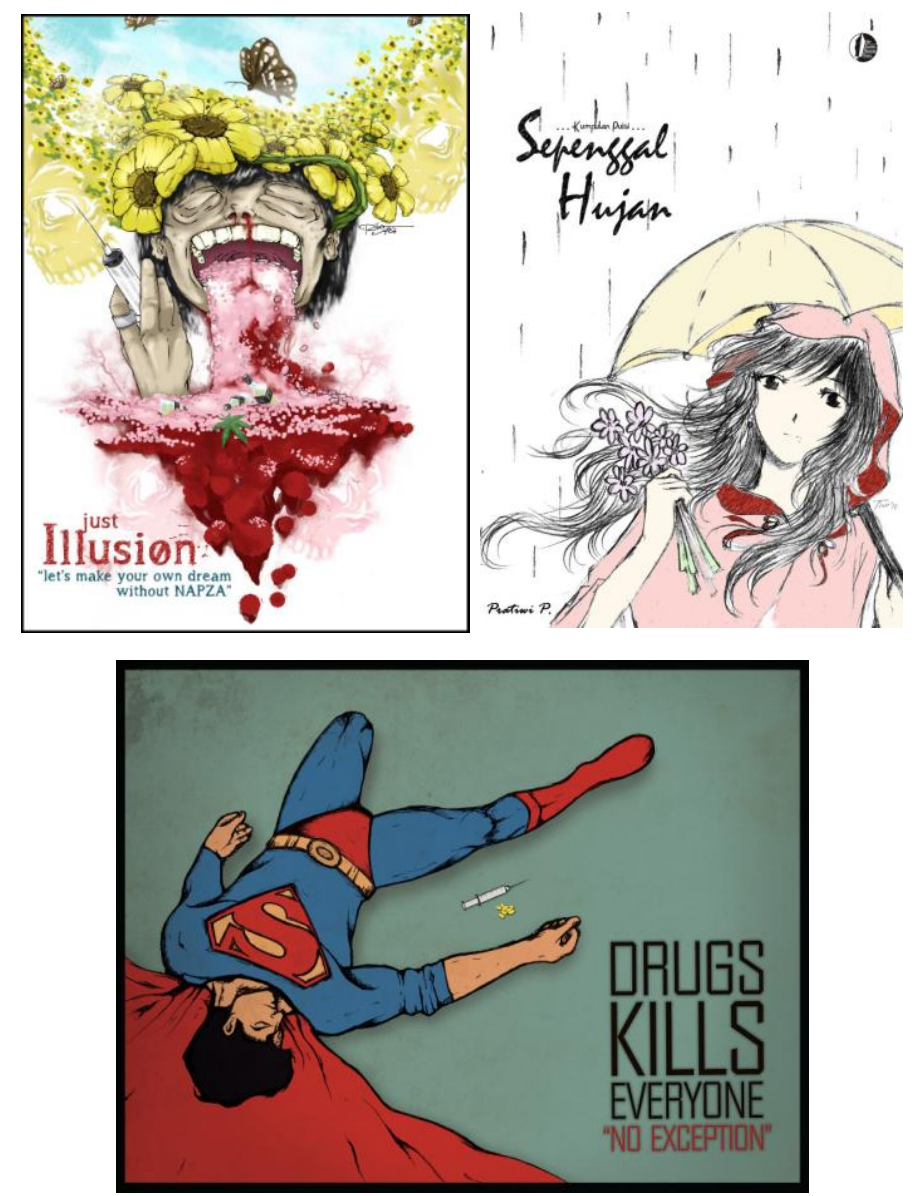

Fig 5: Combination Tecnique (Manual -

Digital)IMPLEMENTATION

\section{a. Showing Main Messages of Book on Book Covers}

A cover of book, including the front and the back, is useful to keep the content of book bound together [23]. Inevitably, nowadays many books are sold online therefore show only their front covers [24] [25] [26] [27]. Hereby, the use of book cover develops from it being guard in to a medium to show readers messages so that can know the main idea the book tells about. Thus, the occurrence of design software is sufficient to help make book covers more interesting, attractive, eye-catching, and esthetic. It is undeniable that book covers could play more important role than the contents in inviting people to read. Finally, the more interesting the cover is, the more interested readers therefore pick the book and put it in their shelves.

The following two pictures below are examples of book covers. The left one shows a figure who was famous in Indonesia for the last four years; the deceased Mbah Surip. The book wholly tells about Mbah Surip when he was alive. The figure is drawn and designed using vector and not anything included in the cover but him. Therefore, the book cover could tell that it is all about him, no more. Next, the other book cover is designed which is designed by the writer himself shows love in digital using vector. In accordance with the title of the book, "1 Cincin 4 Cinta" (1 Ring, 4 Loves) the 
design is made to match the title; four females and one male. They are drawn using vector technique. The two book covers have now been made so attractively that the designer could be very satisfied, for the readers could catch what the designer wants to say through the images.

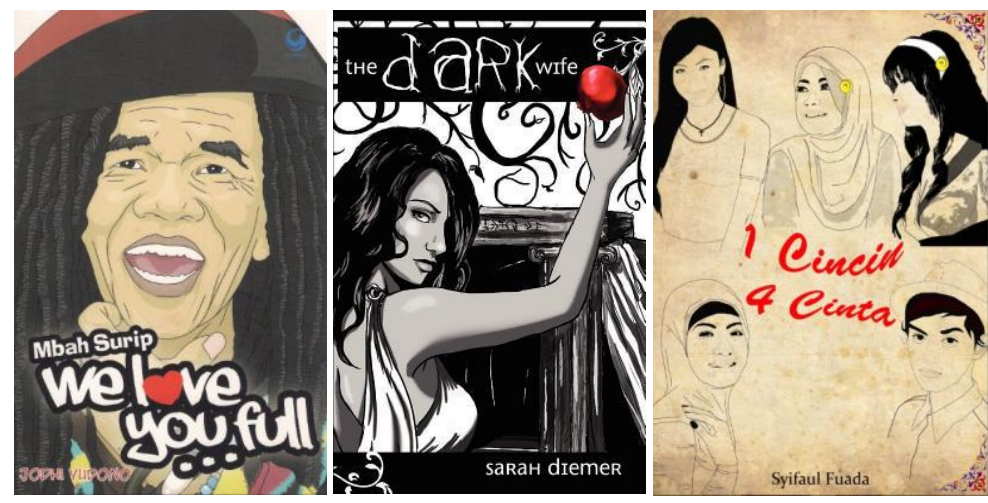

Fig 6: Front cover of the book

\section{b. Expressing Feeling to People in Surroundings}

As well as implementing the digital design to express meaning in the cover of book, digital design could tighten relationship and fellowship among people and their surroundings. Then, it could be used to show how someone feels about others. Thankful, grateful, glad, and loving are some of expressions which the digital design could express. Still, it can help show how someone supports another. The following are some examples of design along with the expressions attached; "Best Friend Forever", "Keep Moving On, My Friend”, "Guyub Rukun", and "A Happy Family".
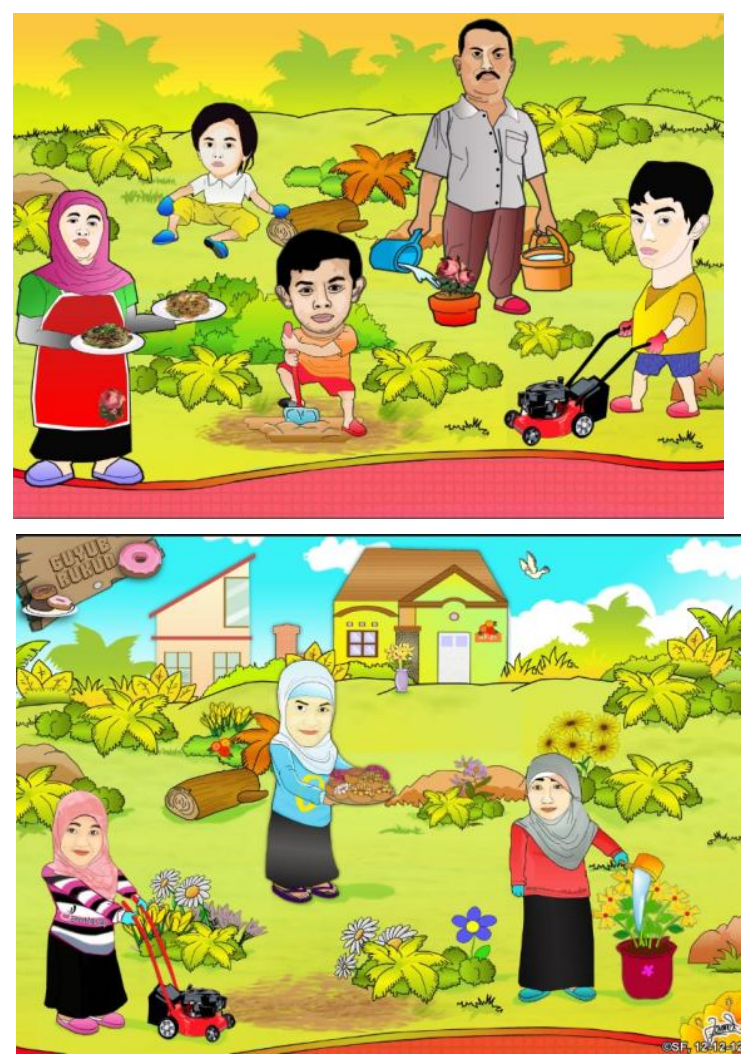

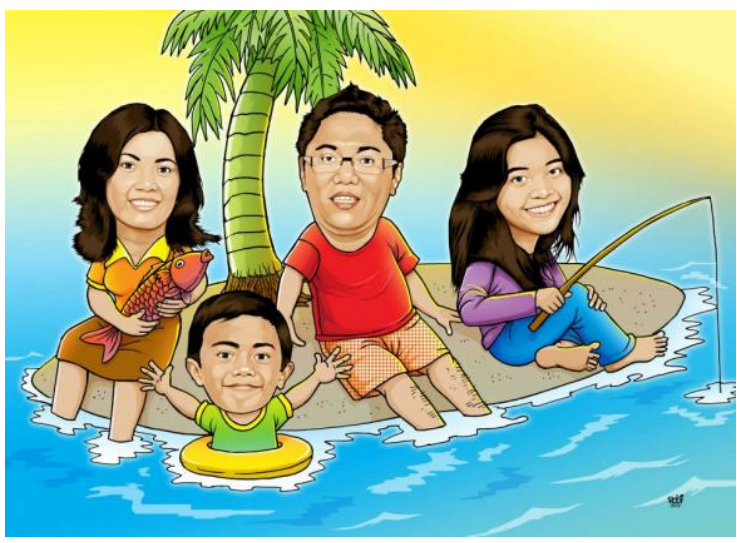

Fig 7: Examples of Designs Expressing Feeling to Surroundings

If once you are supposed to give a gift as surprise to your friends, you design digitally. Then, you can either print it out or send it to their email addresses and other online social networking. After that, you wait. Your friends might send you a thank you short message with a smile emoticon (;) attached, or they might tag your name in their updated status on Facebook of their thanks and smile emoticons. Now, you have pocketed the smiles, digital expressions for you.

\section{c. Saying Happy Birthday through Cards}

If showing gratitude can be undergone using digital design, then saying happy birthday will just be the same. The following designs are examples which can be made using Photoshop, Corel Draw, and Illustrator. One of which are made by the writer himself to say happy birthday to his friend and some are downloaded from the Internet.

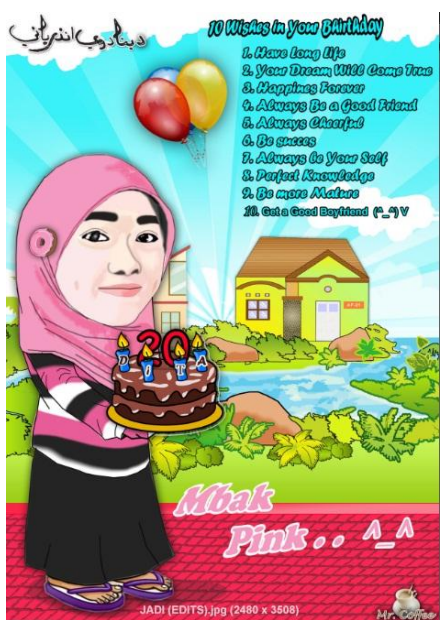




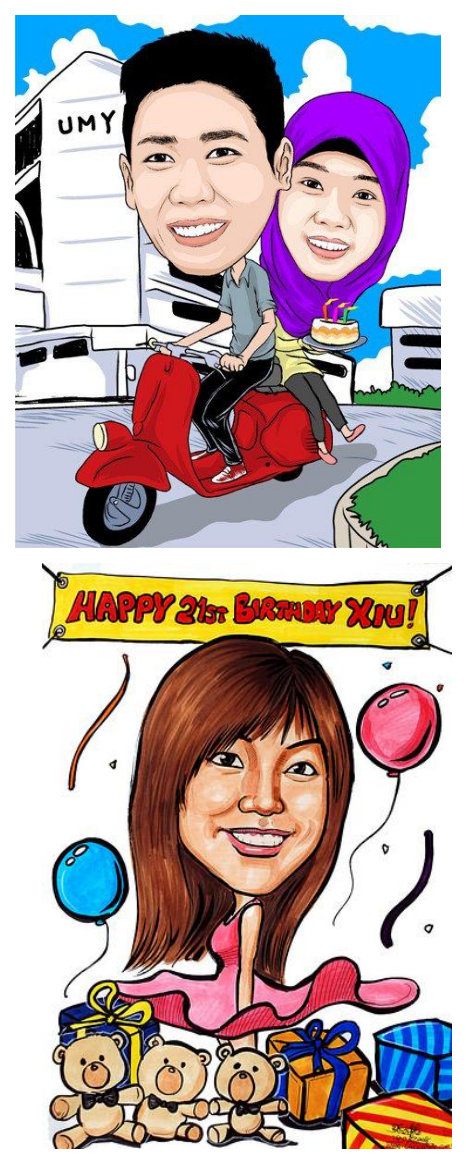

Fig 8: Example of Happy Birthday Cards and Posters

In designing happy birthday cards or posters, some favorite things of people celebrating are important to be included, like favorite food, pets, dolls, colors, and clothing as well. Besides, wishes, balloons, presents, and a "Happy Birthday" banner [22] can be attached to beautify the card or posters. On the one hand, if the celebrating people are sweethearts, the messages of saying happy birthday can be expressed through images of the two loving couples together. When the design is done, print it out to the ISO standardized paper and give it to the celebrating birthday person, or send it through the e-mails or other social networking sites and say "Happy Birthday" with a smile emoticon [6] [7] [8] [9] [16].

\section{d. Expressing Idea on Posters for Competition}

In its implementation, digital expression is not merely shown in the book covers, gratitude posters, and birthday cards. Digital expression does exist in posters for competition purposes. However, the messages expressed in the posters should match the theme of requirements decided by the competition committee. One of examples is a poster under a theme of Work Health and Safety (In Indoensia: Kesehatan dan Keselamatan Kerja). In the poster, the writer as well as designer would like to express the message that everyone should consider wearing safety stuff while working, such as helmets and goggles. Besides, there is another poster competition whose theme is IT for Everything. In the poster, a man, who is engineered to vector form, is enjoying using the internet.

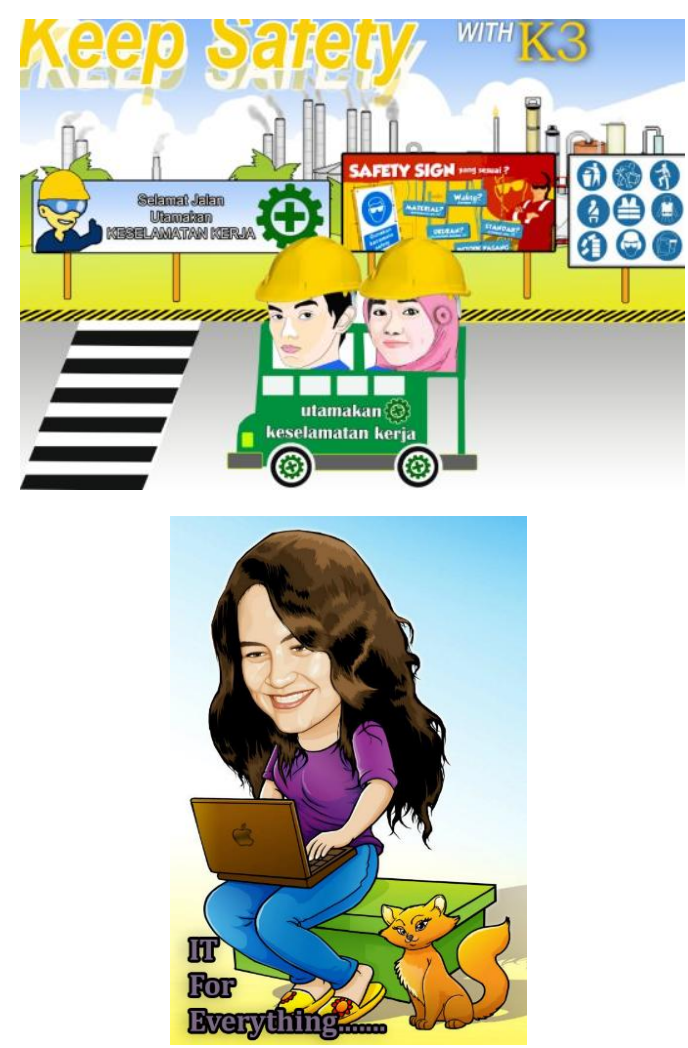

Fig 9: Examples of Posters Expressing Idea for Poster

Competitions

\section{CONCULUSSION}

So far, there have been some studies conducted in relation with facial sketching, including sorrow, joy, anger, and so on. The facial sketching is done on interface controlling system basee on simple strokes on a $2 \mathrm{D}$ canvas and 3D control models [33]. However, this article tries to describe an integrated theory about digital expression, which may be referred to all kinds of feeling within ourselves and expressed into designs, and then it is so-called pictorial message. In fact, expressing in words could no more be sufficent because there is a number of expression not finding 'clicked' words, even if so, it would take too long sentences. Essentially, things we feel inside our hearts can be put on designs. In line with the advanced tech, it is, then, helpful to exploit a variety of facilities provided. Moreover, not merely experts can make use of the tech, but everyone who is willing to. For example, you create a full color image with a black background and graffiti like tangled; it then indicates that your psychology is in problem. Actually, there are can do to elicit what we feel deep down our hearts. This this paper then comes to describe small parts of a series of expression, such as (1)In the front cover of a book, so if you are an author, you can include to your book people's appearance inspiring you, or even the one your heart sticks to. (2)Drawing people in our live, describing all people around you, the people your love or family. (3)Say, Happy bhirthday!, a design by you for your most special person,. (4)Submitting for a design contest, if you want to, you can read the theme of competition. Afterwards, you make a related design. Finally, you can express and motivate people with 'Express yours to the world' 


\section{ACKNOWLEDGEMENT}

We would like to acknowledge our friends for giving idea and concept for design process. Then to my friends in SETROUMB, INKUBATOR UKM PENULIS UM. Some of the pictures are the author's own design and some other are from the internet. So, here I acknowledge to the sites that publish and share their creativity of digital design by online media like: UKM GERMAN UM, vektor.Tutpulus.com, photoshoplady.com, karikatur.indonesia, Mr. Robby Gandamana at Tukang Gambar Facebook fanspage [40], Bang Shiro at Kartun Ngampus, devianart galery. Then to our friend at UKMP UM for her cover model her book [39]. Then to a friend of ours from Deparment of Mathematic and Science: Dita Dwi Andriyani. Not to mention, our family that never stop supporting and motivating to us. Finally, we acknowledge the INTERNATIONAL JOURNAL OF COMPUTER APLICATION (IJCA), ISSN: 0975-8887 that opens an opportunity for us to publish this scientific article, in MAY ISSUE, VOLUME ** No ** 2013

\section{REFERENCES}

[1] Design Thinkers. 2011. Accessed from: Digital Technology's Impact on Design and Design Thinking. Retrieved

\section{at} http://rgddesignthinkers.wordpress.com/2011/06/16/digit al-technologys-impact-on-design-and-design-thinking/. Retrieved at January, 31 - 2013

[2] Indriastuti, Farida. 2012. Nasehat Kreatif yang Menggugah. http://satulingkar.com/detail/read/2/387/nasehat-kreatifyang-menggugah. Retrieved at January, 31 - 2013

[3] Suggest Poster From Marshallfoundation.org. File Accessed from: http://library.marshallfoundation.org/posters/library/poste rs/poster_full.php?poster=688. Retrieved at January, 31 2012

[4] Rima. Poster Kritikan untuk BEM. 2011. File Accessed from: http://www.mikafip.com/2011/07/poster-kritikanuntuk-bem.html. Retrieved at January, 31 - 2013

[5] Poster Ajakan Presiden RI (Poster of Presidential Invitation). File Accessed from: http://www.pramukanet.org/index.php?option=com_cont ent\&task=view\&id=334\&Itemid=78\#.UQkvavI4efw. Retrieved at January, 31 - 2013

[6] Gajawada, Satish. 2012. Smile Theory of Everything. International Journal of Scientific and Research Publications (IJSRP), Volume 2, Issue 10, October 2012 1 ISSN 2250-3153. File Accessed from: http://www.ijsrp.org/research-paper-1012/ijsrpp1025.pdf. Retrieved at February, 1 - 2013

[7] Gajawada, Satish. 2012. Smile Theory of Everything. International Journal of Scientific \& Engineering Research (IJSER), Volume 3, Issue 10, October-2012 1 ISSN 2229-5518. File Accessed from: http://www.ijser.org/researchpaper\%5CSmile-Theory-ofEverything.pdf. Retrieved at February, 1 - 2013

[8] Gajawada, Satish. 2012. Smile Theory of Everything. IOSR Journal of Humanities and Social Science (JHSS) ISSN: 2279-0837, ISBN: 2279-0845. Volume 2, Issue 1 (Sep-Oct. 2012), PP 56-58. www.iosrjournals.org. File
Accessed from: http://iosrjournals.org/iosrjhss/papers/Vol2-issue1/J0215658.pdf. Retrieved at January, $18-2013$

[9] Gajawada, Satish. 2012. Smile Theory of Everything. RESEARCH INVENTY: International Journal of Engineering and Science ISSN: 2278-4721, Vol. 1, Issue 5 (October 2012), PP 13-16. File Accessed from http:/www.researchinventy.com/papers/v1i5/B01501301 6.pdfRetrieved at January, 17 - 2013

[10] Digital Image File Types Explained, accesed from: http://users.wfu.edu/matthews/misc/graphics/formats/for mats.html. Retrieved at January, $30-2013$

[11] Caroline. 2010. The 5 Types of Digital Image Files: TIFF, JPEG, GIF, PNG, and Raw Image Files, and When to Use Each One. Accessed from: http://www.ivanexpert.com/blog/2010/05/the-5-types-ofdigital-image-files-tiff-jpeg-gif-png-and-raw-image-filesand-when-to-use-each-one/. Retrieved at January, 30 2013

[12] Digital Image File type. Accessed from: http://www.sphoto.com/homedd/filetypes.html. Retrieved at January, 30 - 2013

[13] Fuada, Syifaul. 2013. Jurus Ampuh Photoshop CS5. Malang: Hafeey Publisher (ISBN: 978-602-7876-20-0)

[14] Guide to International Paper Sizes. Accessed from: http://www.edsebooks.com/paper/papersize.html. EDS Inc. Retrieved at January, $30-2013$

[15] Wikipedia. 2013. ISO 216. Modified at January, 9 2013. Accessed from: http://en.wikipedia.org/wiki/ISO_216. Retrieved at February, 2 - 2013

[16] Gajawada, Satish. 2012. Smile Theory of Everything. International Journal of Innovative Research \& Development(IJIRD). ISSN 2278 - 0211 (Online). Vol. 1 Issue 8. October 2012. PP 658 - 664. File Accessed from: http://www.ijird.com/vollissue8.pdf.pdf. Retrieved at February, 2 - 2013

[17] Kuhn, Markus. 2006. International standard paper size. Accessed from http://www.cl.cam.ac.uk/ mgk25/isopaper.html. Retrieved at January, $30-2013$

[18] International Paper Sizes \& Formats. Accessed from: http://www.papersizes.org/. Retrieved at January, 30 2013

[19] ISO Paper sizes and specifications. Accessed from: http://www.absolutegraphix.co.uk/trade_paper.asp. Retrieved at January, $30-2013$

[20] Iso And Us Cut Paper Sizes, http://www.paperonweb.com/size.htm.

[21]Tukang Gambar Fanspage. KARINGELANTUR albums. Uploaded foto at December, 4 -2012

[22] Potrait Workshop. 2008. Caricature theme - 21st birthday. Accessed from: http://www.caricature.com.sg/2008/03/caricature-theme21st-birthday.html. Retrieved at February, 02 - 2013

[23] Wikipedia. 2013. Book Cover. Modified at January, 14 $2013 . \quad$ Accessed from http://en.wikipedia.org/wiki/Book_cover. Retrieved at February, $3-2013$ 
[24] see the catolog book's site in: http://www.leutikaprio.com/, indie publisher

[25] see the catolog book's site in: http://www.goodreads.com/list/tag/cover, cover book list

[26] see the catolog book's site in: $\mathrm{http} / / / \mathrm{www}$.gramediaonline.com/, publisher via online

[27] see the catolog book's site in: http://sf.tradepub.com/, the book cover about management book, marketing book, operations book, sales book, and technology book.

[28] Setiyawan, Dwiki. 2009. "Percayalah buku mbah surip yang ini Lain...". Figure File Accessed from: http://dwikisetiyawan.wordpress.com/2009/11/14/percay alah-buku-mbah-surip-yang-ini-lain/. Retrieved at February, 3 - 2013

[29] Facebook. Communication Skill Training 2013. Lomba Desain Poster CST 2013 Album. File Accessed from (http://www.facebook.com/media/set/?set=a.3345036366 53729.68027.312216368882456\&type $=1$ ). Retrieved at April, 4 - 2013

[30] Parmawati, Pratiwi. 2012. Sepenggal Hujan Cover Book. File Accessed from: http://nightformiya.wordpress.com/. Malang: UKMP Publisher

[31] caricatoor from facebook's site, see in: http://www.facebook.com/pages/TukangGambar/125908 037520794? ref=stream. (file accessed at May, 4th 2013)

[32] visit the site: http://www.tucia.com/login/.

[33] José Carlos Miranda , Xenxo Alvarez, João Orvalho , Diego Gutierrez, A. Augusto Sousa and Verónica Orvalho. 2011. Sketch Express: Facial Expressions Made Easy. EUROGRAPHICS Symposium on Sketch-Based Interfaces and Modeling (2011), T. Hammond and A. Nealen (Editors

\section{AUTHOR'S PROFILE}

Syifaul Fuada is an Electrical Engineer, and a Freelance Writer as well as an Independent Designer who lives in Kediri, East Java, Indonesia. He is an assistant at electrical machines worklab, a member of robotic team in UM and the head departement of Inkubator Science in UKMP for 20132014. There were some nonformal education institutions which he was learning in, such as PPPTK/VEDC Malang
(2008), BLPT (2009), and Petrokimia Gresik Factory (June July in 2012). Now, he is a student at electrical engineering department in State University of Malang (UM). Besides, he has also joined some training and workshops to enrich his knowledge, which are Writing Training on Januari 2011, Web Mobile Training on September 2011, Game Animation Training on Oktober 2011, Workshop Solar Cell on Oktober 2011, Power Electronic Training on 17 Oktober - 16 Desember 2011, Workshop of Microsoft Technology on Desember 2011, Power Searching Google Course (Online on July 2012), Robotic Training, Training Design on September 2012, Workshop of Multimedia on October 2012 and Workshop of Internet-Blog and Social Media on February 2013. In addition, he is an active writer that he has published his works in form of writings in East Java regional newspaper, like Surabaya Tribun News, and digital magazine like kampus.okezone, etc. He also published article in International Journal (Online Version). Besides his simple writings, he has also published a book entitled Teknik Photoshop CS5 published by UKMP Publisher in 2012.

Nur Kamilah lives in Situbondo, East Java, Indonesia. She is a student of English Department in Faculty of Letters, State University of Malang. Since she was at Junior High School, she has been so familiar with English that she joined LIPS (Language Intensive Program of SMP Nurul Jadid) for two years and FLDI (Foreign Language Development Institute) for three years. Some achievements she has got from the nonformal education, such as the star student of FLDI for period 2008/2009 and the achiever of the best final paper for advanced level in FLDI in 2009/2010. Besides, there are some competitions she has participated and won, like English debate for High School in Universitas Islam Malang (UNISMA) and University level in IEDC (ITS Open English Debate Competition), English speech for High school level in FB-LPBA (Festival Bahasa-Lembaga Pengembangan Bahasa Asing), and Scientific Paper (KIR) for High School level held by IPMOMI-Paiton Energy. She is now starting up her career as a teacher and writer by joining private teaching in some institutes in Malang and UKMP (Unit Kegiatan Mahasiswa Penulis) in State University of Malang. She has written her first book entitled 'Kumpulan Cerita untuk Adik' and already been published by UKMP Publishing in 2012. Now, she is the secretary of "Inkubator" Science in UKMP for 2013-2014 period. 